\title{
FRAMEWORK SUSTAINABILITY STRATEGY, INHOTIM, BRAZIL
}

Jean Hilgersom ${ }^{1}$

I will give you the overview of the presentation. The start is the introduction of myself as President of ICAMT, what we do and organise. And even so important owner and director of ToornendPartners and the projects we are involved in this moment.

Next follows the introduction of Inhotim, where the museum is, in Brazil, and what kind of buildings there are in the Park, it gives a global idea. This all together with a lot of beautiful and bright pictures of the landscape, the surrounding nature, activities and Belo Horizonte.

Then the step in the direction of the Framework for a sustainability strategy is made.

First with the big question. Why? There are probably a thousand reasons why sustainability for Inhotim gives value, although reasons in the sense of resources, future and children are good to name, it is also about efficiency and money. The Framework has three dimensions: museum, sustainability and strategy. In the presentation these dimensions are explained.

The first dimension is the museum. The museum contains the elements of collection, people and building. These three effects each other all the time and it is, whatever you want, plan or do, the task of the museum staff to keep these three elements in balance.

\footnotetext{
${ }^{1}$ President of ICAMT hilgersom@toornend.com
} 
This is the daily job of the Inhotim organisation, find out what is best for the collection, what is best for the gardens and building and what is best for all he visitors. The awareness of this is essential for the approach we will follow.

Sustainability is the second dimension, and we've thought it is important to make a connection with the sustainable development goals of the United Nations. These are very well conceived, agreed and written down on the website of the UN, and there is also a very nice working app available for your iPhone and iPad. Most of the UN countries agreed on all these themes and future goals. We propose to bring these global goals to the local goals of Inhotim. And that's why we have to make a joint with the first dimension, the museum.

This results in the UN goals: Healthy Lives, Water and Sanitation, Energy for all, Consumption and Production and the last Implementation and Partnership. Translated to the museums these could be successively: Indoor Air Quality, Water Use, Energy Use, Material Use and Management.

The third dimension is Strategy. This dimension is to get everything moving. And of course, moving in the direction you will achieve.

Here we pick up the "good old" and proved method of $\mathrm{Mr}$ Deming, the Deming Circle or PDCA circle. Plan, Do, Check and Act. This is a circular movement what never stops and improving all the time. Elements of the Japanese method Kaizen could also take into account. This is the essence of sustainability, it never stops, it improves all the time.

Knowing that sustainability never stops, and that every step, even when this is a small one, is important. It gives Inhotim the power for improvement. The condition is that you have to know where the start is, that you measure what you do, analyse the results to make a step upwards, raising the standards. The keys of Strategy, this third dimension, is a process and the phases in this process are Visionary thinking, Defining, Designing, Preparing, Implementing, Monitoring, Analysing and Improving. And this leads 
again to Visionary thinking. It's even better to say that this gives the Inhotim organisation the drive to improve.

And Inhotim is already on the spot, it is not necessary to start from scratch, all the keys are there and can be turned, if Inhotim likes.

We can conclude that all the three dimensions of the framework are there: Museum - Sustainability - Strategy. The museum what needs the balance, the goals for sustainability and the strategy to get there, or even better to raise the standard. Now it's time to build the framework for Inhotim. Building is always an adventure, building is unique, finding new paths and insights. Don't make it difficult, keep all involved informed, otherwise you lose commitment and that's the start to lose control.

You must be aware that nothing is difficult, nothing is complicated, although it is sometimes hard to explain, the framework is the instrument to find and have the appropriate arguments you need for explanation, communication and commitment.

When we start with building the structure, whatever you do, find a reason why you do it, why it is important for Inhotim, what does Inhotim want to accomplish. This is the vision, the vision of Inhotim. The vision for Inhotim for the sustainability goals. Vision is about something Inhotim wants to reach on the long term.

What could be the vision of how to use energy, water, materials. What are the needs of these in your museum, for your collection, building or the people, visitors and staff? Is the collection growing? How long are the visitors staying in the museum, is the capacity of the public facilities adequate, what is the impact for the organisation, for the museum. etc. etc. There are lots of ideas to think about, and think about these for the long run, the future. What are the needs over 5 year, over 10 year?

It is not necessary to solve everything at the same time. The framework gives the room and opportunity to plan the visions and make steps. The steps won't have the same size for each measure, there are larger steps and smaller steps. 
And don't forget, small steps are also steps, isn't it? The output of this phase is the vision of Inhotim with all the sustainable goals on the short and long term.

You will understand that the output of each phase is the input for the next phase. Communication is a major aspect in the process. It should be clear what is expected in each phase and what will be delivered, when there are doubts, communication is the only way to avoid misunderstandings.

\section{$* *$ Vision**}

Every project starts with a vision, bright view for the future. A long-term idea about sustainability for Inhotim. Where will Inhotim be in 20 years. What will Inhotim mean for the surrounding. How efficient will the organisation develop, and how will it be an attractive place for visitors in the future.

This vision could be big, and it should have commitment to make next steps in the project, next steps for the development of sustainability.

\section{**Defining**}

In this phase of defining the vision will be translated into possible sustainability measures, what will be the impact of these measures, and how to choose? Therefor there are several available tools, like risk and opportunity assessments, analyse the strength and the weaknesses of Inhotim. With these tools you are able to develop the measures.

With the tool Life Cycle Cost Analyse measures could be compared and Inhotim is able to decide which measure is most effective. This is a decision generated by money, at the end most of the time it's a matter of money, but other criteria, and impacts could be taken into account as well.

\section{**Designing**}

This is the phase in which the measures are designed, these are named in the definition phase. Actually, design the result of the 
definition phase. The design start with deepening, the definition results, this could be done by developing scenarios., and the exact

\section{**Preparing**}

Preparing is the technical design, brings the conceptual design further, into technical details. The quality of the results of this detailing, makes it possible to work on the planning of the execution and then it is possible to find out where the possible pitfalls are, and who could be responsible for these pitfalls. When the execution will take place, it will affect several organisational aspects, probably the visitors. Policy had to be developed about this as well as health and safety for the people, staff and visitors, and the buildings. Also, important to think about are permits of local government, these could be needed. And what about procurement, the contractors should have sustainable way of working, and are to able to guarantee this by certification.

\section{**Implementing**}

This is phase of execution the measures, actually that is quite simple, the execution from everything what is thought out in the previous phase. You will find out of all the aspects are designed well, and it is obvious that you would need some flexibility and probably budget to solve upcoming problems.

But the time is needed, to prepare aspects for the development of the operation strategy, again risk assessment, with the focus on the operation. The change and control procedures, what will be the impact for the visitors., and is it wise to develop your way to communicate the results of the sustainability in the period of operation. Even when the results show only small improvements, then it is wise to communicate the way you do the implementation of sustainability in Inhotim, everyone understands that it is a long road in which you improve constantly.

\section{**Monitoring**}


The next phase is the phase where we all were waiting for: it is the start of the in-use period. Inhotim is able to experience what the effects are of the sustainable measures. What does it bring and what it is the impact for the operation?

This phase is the Monitoring phase. In the monitoring phase of this sustainability project measurements are made. Measurements from. Everything what is important, collecting all the data, to measure the results of all the implement sustainability items. This starts with writing a plan of measurements, what will be counted and what can you do with the results, so that the analysing of the next phase will be effective. Measuring performance is possible by using sensors, just counting, and log instruments. A lot of values could be measured, like the weather, temperature inside and outside, humidity, number of people inside the building, how long are they staying, what is the energy-use during day-time, nighttime. What's is the CO2 inside the building, where are the deliveries come from, what are the certificates deliveries need, etc.

\section{**Analysing**}

All the data we have collected could be analysed, all kind of methods are available to analyse, counting averages etc. And what about feedback from the visitors, how do they experience the way sustainability plays a role in Inhotim, and what do they expect from sustainability in Inhotim.

Tools like prediction and disruption could help to analyse the data and figures. This analysation gives the input for the development of new policy.

\section{**Improving**}

The process leads to new ideas, innovation. The redefinition or development of the new policy, what could be possible for the nearby future. The development of sustainability makes steps, small steps are also steps. This development goes hand in hand with the development of the organisation, and the efficiency of the internal processes. 
Important is that commitment with staff members and with the visitors will develop as well, and the communication withal the people keeps this commitment up to date.

\section{**New Vision**}

The improvement of ideas, policy and commitment leads to a new vision, development of a new sustainable horizon, and the whole process starts again, it is rolling. Rolling the standard to a new level, raising the quality of the visitor experience and the quality of the organisation to a higher level.

This new sustainability horizon gives the opportunity to set new long-term goals.

\section{**Framework**}

This is the framework with the three dimensions: museum, sustainability and strategy.

The museum needs to be in balance, the three elements collection, building and visitors needs to be in balance. And although these needs are constantly moving and changing the framework of sustainability and strategy gives a solid base to develop improvements for the needs and balance.

\section{References}

Castanheira , Y.; Rodrigues, D. \& Arantes, L. (Orgs.). (2017). Inhotim Transverso. Brumadinho: Instituto Inhotim.

Coelho, Frederico. Futuromemória : Inhotim tempo espaço / Frederico Coelho, Dantes Leblon Editora, Livraria Ltda. Brumadinho: Instituto Inhotim, 2016.

Cunha, M. L. (2016). Quando o mercado invade o museu: a dinâmica das instituições culturais na pós-modernidade: os casos de Inhotim (Brasil) e Saint Louis Art Museum (EUA). Tese de doutorado , Faculdade de Ciencias Sociais, Universidade Federal de Goias, Goias, Brasil. 
Faria, D. M. C. P. (2012 ). Análise da capacidade do turismo no desenvolvimento econômico regional : o caso de Inhotim e Brumadinho . Tese de Doutorado , Faculdade de Economia , Universidade de Alicante , Espanha ; Faculdade de Ciências Econômicas, Universidade Federal de Minas Gerais, Belo Horizonte, Brasil.pp. 344

M ello, P. C. B. (2015). Site Specific na arte contemporânea: Inhotim. Tese de doutorado, Escola de Comunicações e Artes, Universidade de São Paulo, São Paulo, Brasil, Pp.196

Volz, Jochen. Desdobrando uma instituição: Descobrindo Inhotim. In: Através Inhotim / Adriano Pedrosa, Rodrigo Moura (org.) tradução para a língua portuguesa de Izabel M urat Burbridge, Julia Debasse e Ana Ban. Brumadinho, M G: Instituto Inhotim, 2015

Werneck Humberto . (2017) Inhotim, um estado de espírito, Dantes, pp.236, ISBN: 1580118220228

Webert, Fernandes de Souza ,. Inhotim de paisagem a paisagem cultural : resistências e rupturas em Brumadinho / M G. Comunicação de pesquisa realizada no 4을 Colóquio Ibero-americano Paisagem cultural, Patrimônio e projeto, realizado em Belo Horizonte (M inas Gerais, Brasil) de 26 a 28 de setembro de 2016. 